\title{
LDL receptor knock-out mice show impaired spatial cognition with hippocampal vulnerability to apoptosis and deficits in synapses
}

\author{
Shao-hua Wang ${ }^{1 *+}$, Yan Huang ${ }^{2+}$, Yang Yuan ${ }^{1}$, Wen-qing Xia', Pin Wang ${ }^{1}$ and Rong Huang ${ }^{1}$
}

\begin{abstract}
Background: Evidence from clinical studies support the fact that abnormal cholesterol metabolism in the brain leads to progressive cognitive dysfunction. The low-density lipoprotein receptor (LDLR) is well-known for its role in regulating cholesterol metabolism. Whether LDLR involved in this impaired cognition and the potential mechanisms that underlie this impairment are unknown.

Methods: Twelve-month-old Ldlr-/- mice $(n=10)$ and wild-type littermates C57BL/6 J $(n=14)$ were subjected to the Morris water maze test. At 1 week after completion of the behavioural testing, all of the animals were sacrificed for analysis of synaptic and apoptotic markers.

Results: The plasma cholesterol concentration of Ldlr-/- mice was increased moderately when compared with C57BL/6 J mice $(P<0.05)$. Behavioural testing revealed that Ldlr $-/-$ mice displayed impaired spatial memory, and moreover, the expression levels of synaptophysin and the number of synaptophysin-immunoreactive presynaptic boutons in the hippocampal CA1 and dentate gyrus were decreased (all $P<0.05$ ). Ultrastructural changes in the dentate gyrus were observed using transmission electron microscopy. Furthermore, apoptosis in the hippocampus of $\mathrm{Ldl}$ r-/ - mice was revealed based on elevation, at both the mRNA and protein levels, of the ratio of $\mathrm{Bax} / \mathrm{BCl}-2$ expression (all $P<0.05$ )and an increase in activated-caspase3 protein level $(P<0.05)$.
\end{abstract}

Conclusion: LDLR deficiency contributes to impaired spatial cognition. This most likely occurs via negative effects that promote apoptosis and synaptic deficits in the hippocampus.

Keywords: LDL receptor knock-out, Cognition, Synapse, Apoptosis

\section{Introduction}

Alzheimer's disease (AD) is characterised by extracellular amyloid plaques, intra-neuronal neurofibrillary tangles, cerebrovascular amyloid deposits and a loss of neurons and synapses in specific brain regions [1,2]. The mechanisms are not fully understood. Accumulating evidence from clinical [3-5], epidemiological [6-8], animal, cell culture [9] and genetic studies [2,8,10-12] suggests links between brain cholesterol and the development of $\mathrm{AD}$. Disturbed cerebral cholesterol metabolism is now gaining attentions as a crucial aetiological factor underlying AD. Cholesterol metabolism in the brain is independent of

\footnotetext{
* Correspondence: gyjwsh@126.com

${ }^{\dagger}$ Equal contributors

'Department of Endocrinology, ZhongDa Hospital of Southeast University, No.87 DingJiaQiao Road, Nanjing 210009, PR China

Full list of author information is available at the end of the article
}

levels in plasma [13]. Cerebral cholesterol is highly enriched and is synthesised de novo by glial cells, which also synthesise apoE. The cholesterol is transported by apoE and is taken up by neurons via specific receptors, primarily the LDLR, for synaptogenesis and axonal growth [14].

In the periphery, the LDLR is well-known for its important role in removing cholesterol-rich lipoprotein particles from the plasma to maintain cholesterol and apoE homeostasis. In humans, LDLR deficiency causes familial hypercholesterolaemia $[15,16]$. LDLR is widely expressed in the brain [17-21] and as an important receptor for apoE, LDLR plays a key role in brain cholesterol metabolism and brain function. A cohort study has revealed that LDLR-deficient patients showed a high incidence of mild cognitive impairment [22]. Genetic studies have revealed that LDLR is one of five cholesterol-related 
genes that show the most promising association with a risk of developing $\mathrm{AD}[3,23]$. In AD mouse models, LDLR deficiency aggravates learning deficits and leads to increased apoE levels and amyloid deposits [24,25]. Moreover, the overexpression of LDLR in the brain decreases apoE levels and inhibits amyloid deposition markedly [26]. Furthermore, $\mathrm{Ldlr}^{-/-}$mice show modified transbilayer distribution of cholesterol in synaptic plasma membrane preparations from the brain [27].

The hippocampus has frequently been used as a model system of the brain and used widely for neurological studies. The hippocampus is the key region underlying learning and memory formation, and its normal function depends upon the integrity of its neurons and synapses. The LDLR is widely distributed in the hippocampus [18]. LDLR plays a key role in cholesterol metabolism in the brain. In regard to the hippocampus, we hypothesised that an absence of LDLR may impair hippocampal function and negatively impact cognitive function. In this study, using $\mathrm{Ldlr}^{-1-}$ mice, we imitated disordered cholesterol metabolism in the brain and examined its influence on cognitive performance and the possible underlying mechanisms. Our results will be helpful in understanding the role of LDLR in cholesterol-related cognitive impairment.

\section{Experimental procedures}

\section{Animals and experimental design}

A total of 24 four-month-old male LDLR deficient $\left(\mathrm{Ldll}^{-/-}\right)$ mice $(\mathrm{n}=10)$ and $\mathrm{C} 57 \mathrm{BL} / 6 \mathrm{~J}$ littermates $(\mathrm{n}=14)$ were purchased from the Model Animal Resource Information Platform of Nanjing University. The $\mathrm{Ldll}^{-/-}$mice (stock \#002207, strain name B6.12957-Ldlr ${ }^{\text {tm1Her }}$ ) were introduced from the Jackson Laboratory (Bar Harbor, ME) in 2002 and were originally generated by homologous recombination in cultured embryonic stem cells to produce mice that lack functional LDLR. The mice were then backcrossed to C57BL/6 J mice for ten generations to obtain homozygous $\mathrm{Ldlr}^{-1-}$ mice on a C57BL/6 J background [28]. The mice were housed under standard conditions in conventional cages and had free access to food (standard rodent chow diet, Xietong Organism, Jiangsu, China) and water and were maintained at $21 \pm 2^{\circ} \mathrm{C}$ on a $12 \mathrm{~h}$ light/ dark cycle (lights on at 7:00 a.m.). All of the experiments were conducted in compliance with the National Institute of Health Guidelines for the Care and Use of Laboratory Animals (NIH Publications No.80-23), revised in 1996. The Animal Care and Use Committee of the Southeast University approved this animal study.

After one week of environmental adaptation, both the $\mathrm{Ldlr}^{-/-}$and WT C57BL/6 J mice were subjected to a Morris water maze test to determine their baseline cognitive performance, and the test was performed again 8 months later when the mice were 12 months old. The testing was conducted and scored by experienced observers who were blind to the genetic background of the mice. The body weight of each mouse was measured monthly. At 1 week after the completion of the final behavioural test, the plasma lipids of mice were examined as described previously [29]. The mice were anesthetised using intraperitoneal sodium pentobarbital $(80 \mathrm{mg} / \mathrm{kg})$ and killed. To perform the varied methods that are used for the study of apoptotic and synaptic markers, the hippocampal tissue was extracted immediately before or after mice were perfused transcardially via a left ventricular cannula with $4 \%$ phosphate-buffered paraformaldehyde ( $\mathrm{pH}$ 7.4). At least three mice from each group were used for each measurement.

\section{Morris water maze test}

To evaluate the spatial learning and memory of the mice, Morris water maze testing was used as described previously [30,31]. The mice were tested between 8:00 am and 12:00 pm. The water maze pool (diameter, $122 \mathrm{~cm}$;height, $50 \mathrm{~cm}$ ) was filled to a depth of $30 \mathrm{~cm}$ using water $\left(25 \pm 2^{\circ} \mathrm{C}\right)$ made opaque using milk powder. A black platform $(8 \mathrm{~cm}$ diameter, $1 \mathrm{~cm}$ below the surface of the water) was hidden and was used by the mice as the escape from swimming. The test included spatial acquisition and a probe test and was performed over 5 days. For the spatial acquisition test, during the first four days, the mice were trained with 3 trials per day to locate the platform. The interval between the 3 trials per day is 30 minutes. They were given a maximum of $60 \mathrm{sec}$ to locate the hidden platform and were permitted a stay of $10 \mathrm{sec}$ on the platform. Those who failed to locate the platform were guided to it by the experimenter and were also permitted a stay of $10 \mathrm{sec}$. For analysis, the pool was subdivided into 4 equal quadrants labelled N, S, E and W. The time required to reach the platform (escape latency), the distance swam to the platform, swimming speed and the percentage of time spent swimming in the target quadrant were recorded using a video tracking system (EthoVision Image Analysis 3.1, Noldus Information Technology, Wageningen, The Netherlands). A probe test to assess the degree of memory consolidation after learning was conducted on the fifth day by removing the platform. Each mouse was given a single $60 \mathrm{sec}$ trial, and the time taken to reach the original position of the platform and spent in the target quadrant and the number of platform crossovers was recorded.

\section{Electron microscopy}

Damage to the DG region of the hippocampus often prevents the growth of new born cells during the critical period of memory formation, so ultrastructural changes in the DG were observed using transmission electron microscopy. The DG tissue was extracted under a dissection 
microscope (Zeiss, Germany) and $1-\mathrm{mm}^{3}$ tissue blocks were generated that were fixed and subsequently treated as described previously [32,33]. Morphological changes in nerve cells and synapses were observed using an AMTXR60 digital camera attached to a JEM 1400 transmission electron microscope. We identified mitochondria by the presence of distinctive cristae and a double membrane and mature synapses by the presence of the following features on at least one section: a postsynaptic density, at least three synaptic vesicles within $100 \mathrm{~nm}$ of the presynaptic membrane and a clearly defined synaptic cleft.

\section{Synaptophysin detection}

With regard to synaptic density, we evaluated the number of presynaptic boutons using synaptophysin immunostaining and the gene and protein expression levels of synaptophysin. For synaptophysin immunostaining, the hippocampus was cut into a series of $25-\mu \mathrm{m}$ thick coronal sections using a cryostat (Leica CM 3050; Leica, Nussloch, Germany). For each animal, one subseries of 7 (every 10th) sections was used for free floating immunofluorescence processing and synaptic density analyses. The sections were incubated in PBS-T(0.3\%Triton X-100 in PBS, pH7.4) for $1 \mathrm{~h}$, then in blocking solution for $2 \mathrm{~h}$, and then with rabbit monoclonal anti-synaptophysin (Abcam, 1:1000) overnight at $4^{\circ} \mathrm{C}$. After washing, the sections were incubated for $2 \mathrm{~h}$ with FITC-conjugated goat anti-rabbit IgG (Jackson, 1:100) and then incubated for 10 min with DAPI to stain the nuclei. To quantify the density of synaptophysin-immunoreactive presynaptic boutons (SIPBs), CA1 and DG regions within the hippocampus of both hemispheres were assessed in each section. Three randomly chosen areas of the CA1 and DG were examined by capturing confocal images using a digital camera (F-view; Olympus, Tokyo, Japan) attached to an Olympus AX-70 microscope $(100 \times$ oil immersion objective and a $10 \times$ projection lens). In total, 12 confocal images per section and 84 images per animal were obtained (3 images $\times 2$ areas $\times 2$ hemispheres $\times 7$ sections). For the quantification of the synaptophysin fluorescence signal, images of labelled boutons were acquired using the same settings. SIPBs were measured using Image-Pro Plus software (Media-Cybernetics, Silver Spring, MD), as previously described [34,35]. Appropriate background correction was first completed, and the immunoreactive presynaptic boutons were then counted in sampling fields. The SIPB density per unit area $\left(100 \mu \mathrm{m}^{2}\right)$ was calculated. The data from individual animals of each group were pooled.

\section{Real-time RT-PCR}

Real-time RT-PCR was used to investigate the mRNA expression level of synaptophysin and the apoptosisrelated genes bcl-2, bax and caspase 3 to analyse synaptic density and neuronal apoptosis. Total RNA was extracted from the hippocampus using a trizol reagent kit (Invitrogen). Total RNA (1 $\mu \mathrm{g})$ was used as a template for first-strand cDNA synthesis using random primers and the Promega RT System. All of the PCR primers were designed using the Primer Premier 5.0 software (Table 1$)$. The cDNA template $(1 \mu \mathrm{L})$ was mixed into the Master Mix (including $10 \times$ SYBR Green PCR buffer, $25 \mathrm{mM} \mathrm{MgCl}_{2}, 2.5 \mathrm{mM}$ dNTP, 10,000× SYBR Green and Taq DNA polymerase) together with $20 \mu \mathrm{M}$ of each primer. The reaction mixture was brought up to a final volume of $25 \mu \mathrm{L}$ with RNase-free deionised water. The amplification conditions were $2 \mathrm{~min}$ at $30^{\circ} \mathrm{C}, 10 \mathrm{~min}$ at $95^{\circ} \mathrm{C}$ (Taq DNA polymerase activation), followed by 40 cycles of $20 \mathrm{~s}$ at $94^{\circ} \mathrm{C}$ (denaturing), $20 \mathrm{~s}$ at $55^{\circ} \mathrm{C}$ (annealing) and $30 \mathrm{~s}$ at $72^{\circ} \mathrm{C}$ (extension). Real-time RT-PCR was performed by monitoring the increase in fluorescence intensity of the SYBR Green dye using a RotorGene 3000 real-time PCR apparatus (Corbett Research) according to the manufacturer's instructions. All of the measurements were performed in triplicate. The realtime RT-PCR data are represented as Ct values, where the $\mathrm{Ct}$ was defined as the threshold PCR cycle where the amplified product was first detected. Tominimise intraand inter-assay variability caused by differences in PCR efficiency, 5 replicates were performed. The Ct or threshold value of the target sequence is directly proportional to the absolute concentration when compared with the threshold value of the reference genes. The relative expression levels of bcl-2, bax, caspase 3 and synaptophysin were plotted as the fold change compared with the control and were determined using the $2^{-\Delta \Delta C t}$ method (21). This method consists of analgorithm that calculates the relative concentration. The factor $\mathrm{X}$, which is the fold change in the expression of the gene, can be calculated using the following formula: $\mathrm{X}=2^{-\Delta \Delta \mathrm{Ct}}$ where $\Delta \Delta \mathrm{Ct}=(\mathrm{Ct}$ of the target gene - Ct of NAPDH) of the control group - (Ct of the target gene - Ct of NAPDH) of the sample group.

\section{Table 1 The primers for real-time RT-PCR}

\begin{tabular}{ll}
\hline Genes & Primers \\
\hline BCl-2 & 5'- CTGGTGGACAACATCGCTCTG-3' sense \\
& 5'- GGTCTGCTGACCTCACTTGTG-3' antisense \\
Bax & 5'- TCCAGGATCGAGCAGA-3' sense \\
& 5'- AAGTAGAAGAGGGCAACC-3' antisense \\
Caspase-3 & 5'- CATGGCCTGTCAGAAAATAC-3' sense \\
Synaptophysin & 5'- TAACCCGAGTAAGAATGTGC-3' antisense \\
& 5'- CCCTACATTCACCCACTTCTCC-3' sense \\
& 5'- TTATCTCCTCTCTGCCCGTTC-3' sense \\
GAPDH & 5'- TGTTCCTACCCCCAATGTGTCCGTC-3' sense \\
& 5'- CTGGTCCTCAGTGTAGCCCAAGATG-3' antisense \\
\hline
\end{tabular}




\section{Western blotting}

The samples of hippocampal tissue were dissected on ice and washed three times using cold PBS. They were then homogenised in ice-cold lysis buffer $(20 \mathrm{mM}$ Tris, pH 7.5, $150 \mathrm{mM} \mathrm{NaCl}, 1 \mathrm{mM}$ EDTA, 1 mM EGTA, 1\% TritonX-100, $2.5 \mathrm{mM}$ Na-pyrophosphate, $1 \mathrm{mM} \beta$ glycerophosphate, $1 \mathrm{mM} \mathrm{Na} \mathrm{VO}_{4}, 1 \mathrm{~g} / \mathrm{mL}$ leupeptin and $1 \mathrm{mM}$ PMSF). The samples were centrifuged at $14,000 \mathrm{rpm}$ for $15 \mathrm{~min}$. The protein concentration of the supernatant was determined using a spectrophotometer (Thermo). The loading buffer was added, and the samples were boiled for $3 \mathrm{~min}$. Protein $(50 \mu \mathrm{g})$ was then loaded onto a $10 \%$ Bis-Tris gel (Invitrogen). The bands were transferred to apolyvinylidene fluoride (PVDF) membrane, which was then blocked using Tris-buffered saline (TBS) containing 1\% bovine serum albumin and $5 \%$ non-fat milk powder $(\mathrm{w} / \mathrm{v})$. The membrane was then incubated overnight at $4^{\circ} \mathrm{C}$ with anti-bcl-2 (1:1000), anti-bax (1:1000), anti-activated-caspase3 (1:1000) and anti-synaptophysin (1:1000; all from Abcam) primary antibodies. Immunoreactivity was detected using horseradish peroxidase-conjugated secondary antibodies and visualised using enhanced chemiluminescence. The expression levels of each target protein and a GAPDH internal control were quantified using densitometry (TotalLab, version 1.1, UK), and the intensity of each target protein signal was normalised to GAPDH. All of the data were expressed relative to the control and represent the relative expression of each target protein.

\section{Statistical analyses}

The data were analysed using SPSS16.0. The values are represented as the means \pm standard deviations (S.D.) where indicated. A probability value of $P<0.05$ was considered to be statistically significant. MWM spatial acquisition and body weights were analysed using a repeated measures analysis of variance (ANOVA) with genotype (control and $\mathrm{Ldlr}^{-/-}$) as the between-subjects factor and time (days 1-4 and months 1-8) as the within-subjects factor, respectively. Bonferroni-corrected $t$-tests were further used to examine significant differences between experimental time points or between animal groups. The MWM probe test, serum cholesterol, immunofluorescence staining, real time RT-PCR, western blotting and electron microscopy data were analysed using $t$-tests.

\section{Results and discussion}

\section{Body weight gain and lipid analyses}

$\mathrm{The} \mathrm{Ldlr}^{-/-}$mice appeared healthy, and no differences in physical appearance or behaviour in the home cage was apparent between the groups. Repeated measures analysis of variance showed that the body weight of both groups increased steadily $(F(8,196)=197.83, P<0.001)$ over the 8-month period. There was no statistically significant effect of Ldlr deficiency on body weight gain $(F(1,22)=0.15, P=0.71)$. The weight of the C57BL/6 J and $\mathrm{Ldlr}^{-1-}$ mice was $42 \pm 4 \mathrm{~g}$ and $42 \pm 2 \mathrm{~g}$ by 12 months of age. With regard to plasma lipids, we determined the levels of plasma cholesterol, triglyceride, HDL-c and LDL-c. Total (fasting) plasma cholesterol (TC) values were approximately three-fold higher in the $\mathrm{Ldlr}^{-/-}$mice compared with theC57BL/6 J mice $(t(4)=4.08, P=0.02)$ due to an eight-fold increase in LDL-c $(t(4)=3.77, P=0.02)$, whereas there was no significant change in HDL-c $(t(4)=2.31, P=0.14)$. There was no significant difference in plasma levels of triglycerides between the two groups $(t(4)=2.13, P=0.10)$ (Figure 1$)$.

\section{Morris water maze test}

During the baseline MWM test, the escape latencies $(F(3,66)=10.20, \quad P<0.001)$, distances $(F(3,66)=15.16$, $P<0.001)$ and swim speeds $(F(3,66)=11.52, P<0.001)$ decreased in both groups over the 4-day spatial acquisition test period indicating that all of the mice learned the task quickly. However, neither these three above-mentioned indices nor the target quadrant time percentage differed between the groups. For the probe trial test, no differences in the time taken to reach or to stay in the target square, the distance swam and the swim speed or platform crossovers were found between the two groups. These results indicated that $\mathrm{Ldlr}^{-/-}$mice did not show impaired spatial cognition at baseline.

Eight months later, the MWM test indicated that during the spatial acquisition test period, the escape latencies (Figure 2A) and distances swam (Figure 2B) to reach the hidden platform were similarly decreased in both groups over the four testing days $(F(3,66)=8.68, P<0.01)$. No

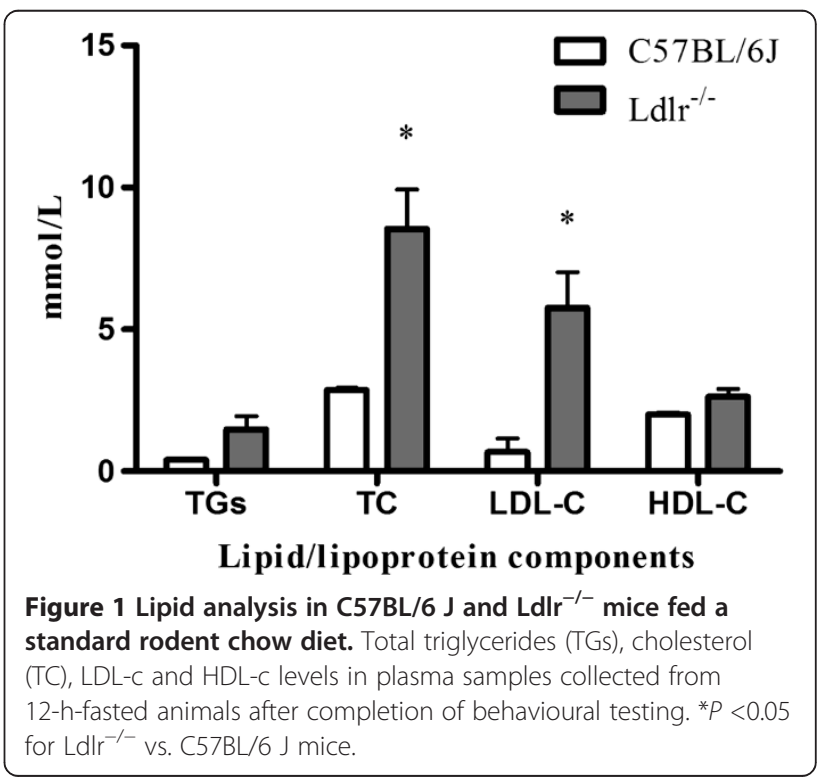




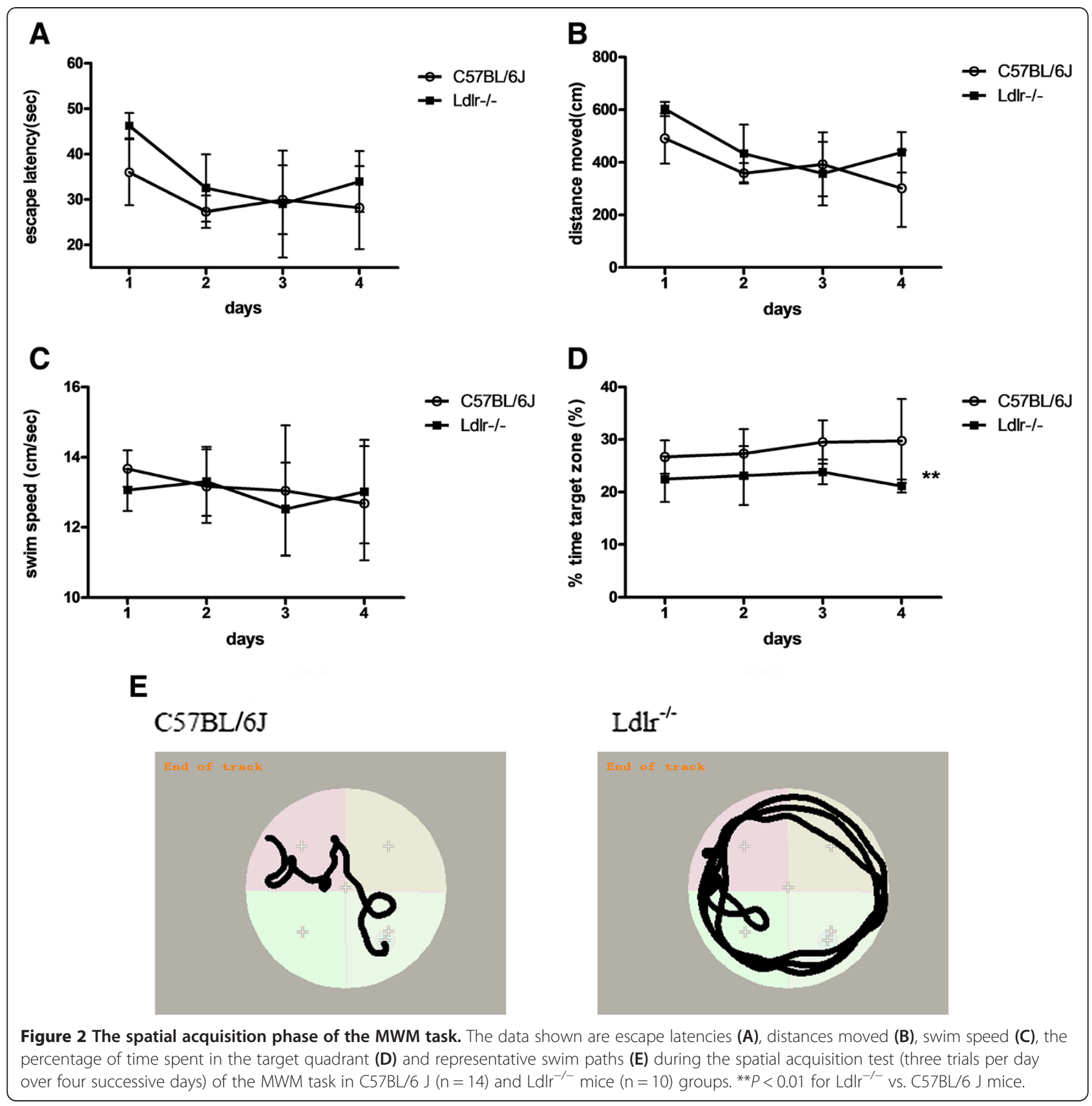

significant differences in swim speed were noted between the two groups (Figure 2C). Repeated measures analysis of variance (ANOVA) showed significant effects of Ldlr deficiency on the reduced percentage of time spent swimming in the target quadrant $(F(3,66)=10.90, P=0.01)$ (Figure 2D), showing a poorer learning performance. Subsequent Bonferroni post-hoc tests confirmed that the percentage time was significantly less on day $3(t=2.74$, $P=0.02)$ and day 4 $(t=2.79, P=0.03) \mathrm{in} \mathrm{Ldlr}^{-/-}$mice. Typical swimming patterns observed on day 4 of the training period suggested that C57BL/6 J mice found the platform primarily by tendency and linear patterns, whereas the $\mathrm{Ldll}^{-/-}$mice swam at the margins, and the swimming patterns were random (Figure 2E). For the probe trial, the platform was removed, and the $\mathrm{Ldlr}^{-1-}$ group failed to remember the precise location of the platform and spent significantly less time in the target quadrant $(t=4.52, P=0.001$; Figure $3 \mathrm{~A})$. No statistically significant differences were noted between the two groups in the time spent reaching the target square,the distance swam or swim speed or in platform crossovers. Typical swimming patterns (Figure 3B) during the probe test showed that the C57BL/6 J mice looked for the platform by shuttling back and forth. In contrast to the 


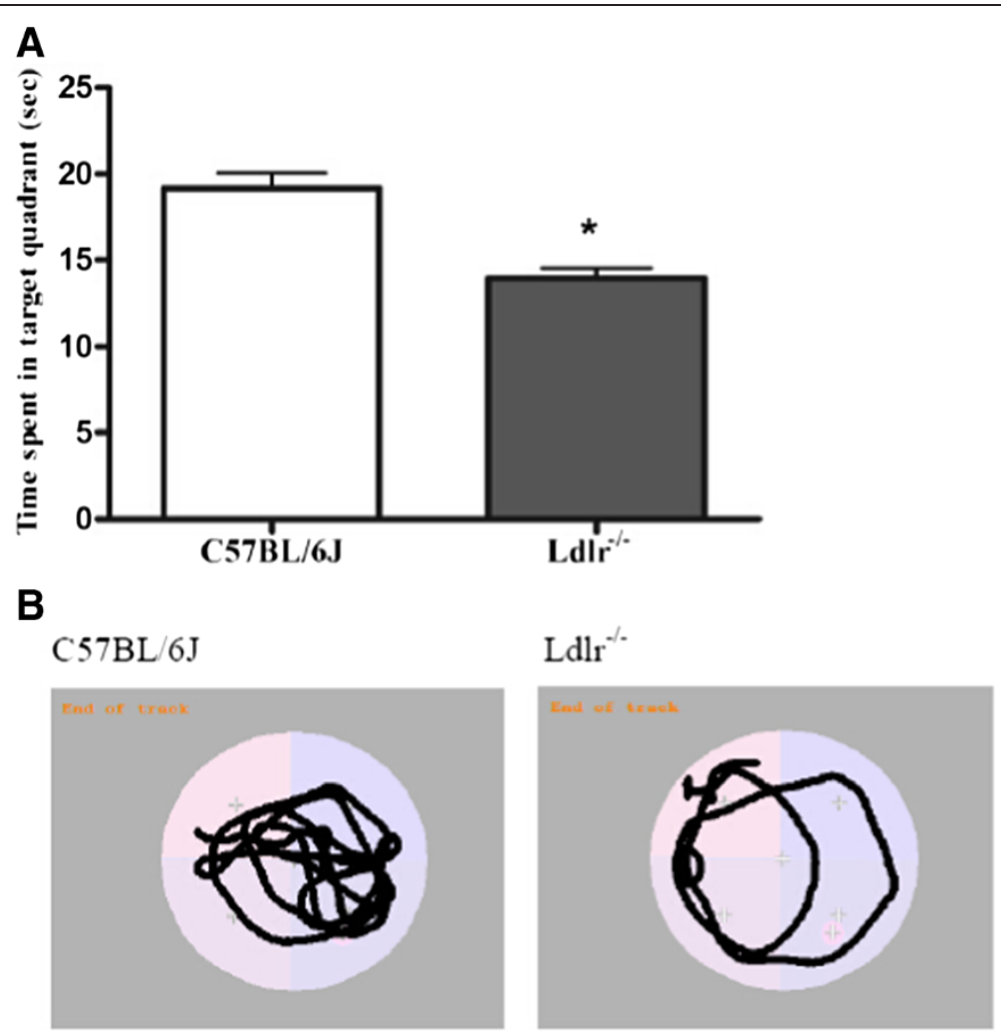

Figure 3 The probe test of the MWM task. The data shown are the time spent in the target quadrant (A) and representative swim paths (B) during the probe test (performed on the fifth day after the first four days of training). ${ }^{*} P<0.05$ for $\mathrm{Ldll}^{-/-}$vs. C57BL/6 J mice.

C57BL/6 J mice, $\mathrm{Ldlr}^{-1-}$ mice swam along the pool border to search for the platform using patterns at the margin.

\section{Electron microscopy}

Ultrastructural analysis of the dentate gyrus revealed robust differences between Ldlr-/- and C57BL/6 J mice. In Ldlr-/- mice, lipid particles were widely distributed in the cytoplasm of glial cells indicating increased intracellular lipid deposition (the " $\rightarrow$ " label in Figure 4Ae). The ultrastructural arrangement was loose and showed oedema (the "\#" label in Figure 4Af). The morphology of the neurofibrils was sparse, and their arrangement was disordered (the " $\square$ " label in Figure 4Ag) which is amplified in (Figure 4Ah). Analyses of synapses showed wider synaptic clefts between the two synaptic membranes and decreased synaptic vesicles (the "*" label in Figure 4Af). In tissue from C57BL/6 J mice, the mitochondria, neurofibrils and synapses showed no evidence of lipid deposition (Figure 4Aa). Neatly arranged mitochondrial cristae and neurofibrils as well as normal synaptic clefts and synaptic vesicles were also observed (Figure $4 \mathrm{Ab}-\mathrm{c}$ ).

\section{Synaptophysin detection}

Synaptic density was measured in the hippocampal $\mathrm{CA}_{1}$ and DG regions using synaptophysin immunoreactivity. Representative images of synaptophysin-stained presynaptic boutons are shown in Figure 4Ba-b. As shown in Figure $4 \mathrm{Bc}$, the SIPBs in the hippocampal $\mathrm{CA}_{1}$ and DG regions were lower in $\mathrm{Ldlr}^{-/}$mice than in C57BL $/ 6 \mathrm{~J}$ mice $(t=3.50, P=0.001 ; t=6.38, P<0.001$, respectively).

The mean protein (Figure 5A) and mRNA (Figure 5B) expression levels of synaptophysin in the $\mathrm{Ldlr}^{-/}$mice, which showed cognitive decline, were lower than in the C57BL/6 J mice $(t=-6.05, P=0.004 ; t=-6.53, P=0.003$, respectively).

\section{Apoptosis and apoptosis-related genes}

The mean ratio of $\mathrm{Bax} / \mathrm{Bcl}-2$ protein (Figure $6 \mathrm{~A}$ ) and mRNA (Figure 6B) was approximately 5-6-fold higher in $\mathrm{Ldlr}^{-1-}$ mice compared with C57BL/6 J mice $(t=6.16$, $P=0.004 ; t=4.37, P=0.01$, respectively). Individually, the mean levels of Bax protein and mRNA in $\mathrm{Ldlr}^{-1-}$ mice with cognitive decline were higher than in C57BL/6 J mice $(t=9.79, P=0.009 ; t=4.68, P=0.009$, respectively) whereas the mean levels of Bcl-2 were lower in $\mathrm{Ldlr}^{-/-}$mice than in C57BL/6 J mice $(t=-7.03, P=0.002 ; t=-8.67$, $P=0.001$, respectively). Moreover, there was no significant difference in caspase-3 mRNA expression (Figure 6D) between the two groups, but activated-caspase 3 protein level (Figure 6C) was higher in the $\mathrm{Ldlr}^{-/-}$mice compared with C57BL/6 J mice $(t=3.07, P=0.04)$. 


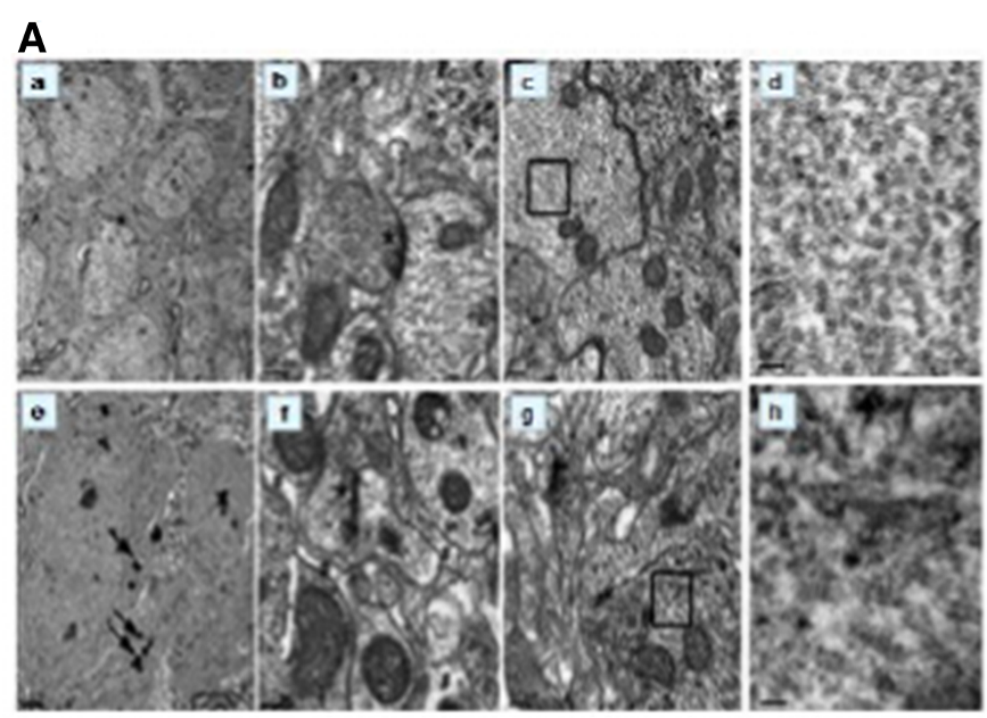

B
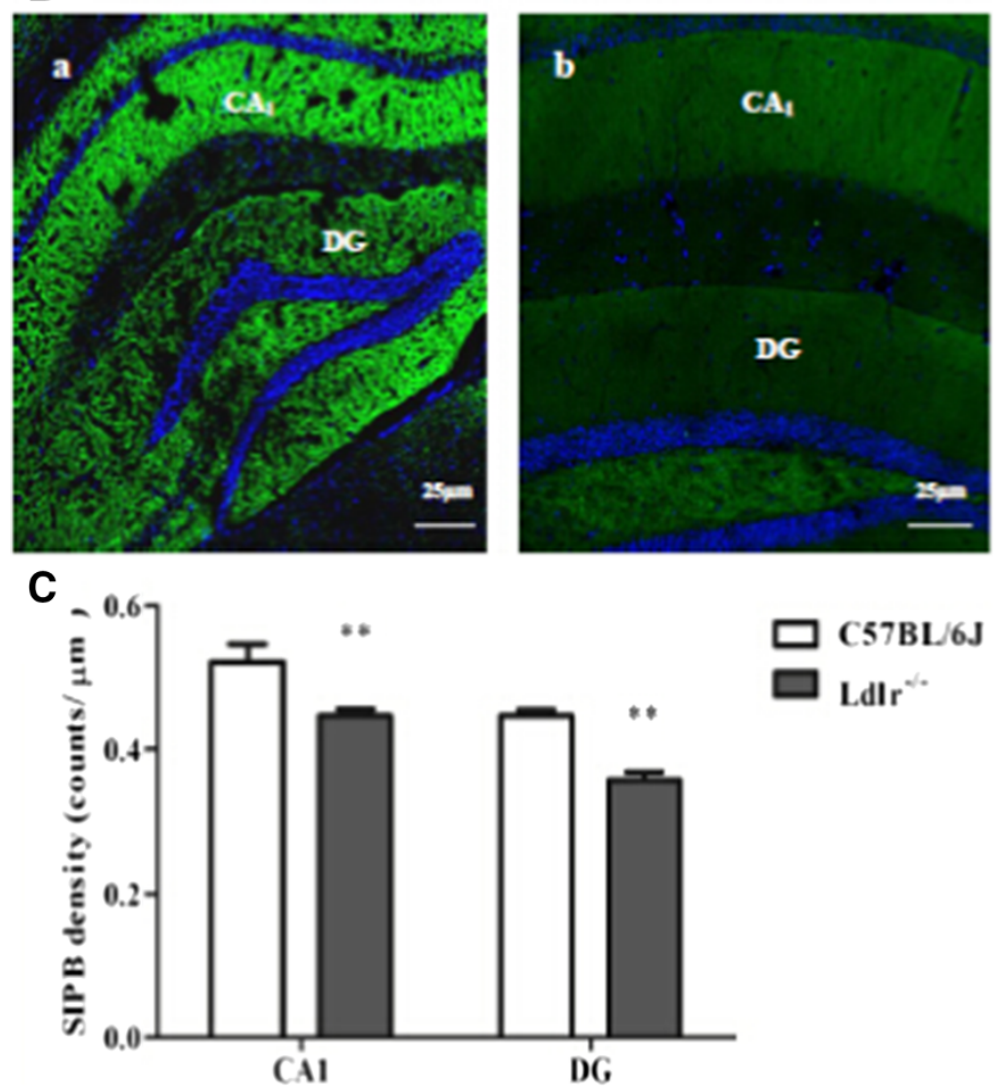

Figure 4 Pathological changes in the hippocampus. A: Electron microscopic examination of the DG stratum radiatum. The data of C57BL/6 J mice shown in a-d are ultrastructural analyses of DG general tissue (a), mitochondrial and synapse ultrastructure ("*" in b), neurofibrils ("ם"in C) which is amplified in (d). the data of Ldlr-/- mice shown in e-h are glial cell lipid deposition (" $\rightarrow$ "in e), ultrastructural loose arrangement and oedema ("\#"in f), a decrease in synaptic vesicles ("*” in f), and sparse neurofibrils ("ם"in g) which is amplified in (h). Scale bar = $2 \mu \mathrm{m}$ in a and e; $0.2 \mu \mathrm{m}$ in b, c, fand g; $0.04 \mu \mathrm{m}$ in $\mathrm{d}$ and h. B: Density of synaptophysin-immunoreactive presynaptic boutons (SIPBs) in the hippocampus of Ldlr-/mice. A representative image of the hippocampus of a C57BL/6 J mouse (a) and Ldlr-/- mouse (b) at 20× magnification is shown. Quantitative data showing a significant decrease in SIPBs in both the CA1 and DG subregions in Ldlr-/- mice (C). Scale bar $=25 \mu \mathrm{m}$ in a and b. ${ }^{* *} P<0.01 \mathrm{for} L d \mathrm{lr}-/-$ vs. C57BL/6 J mice. 


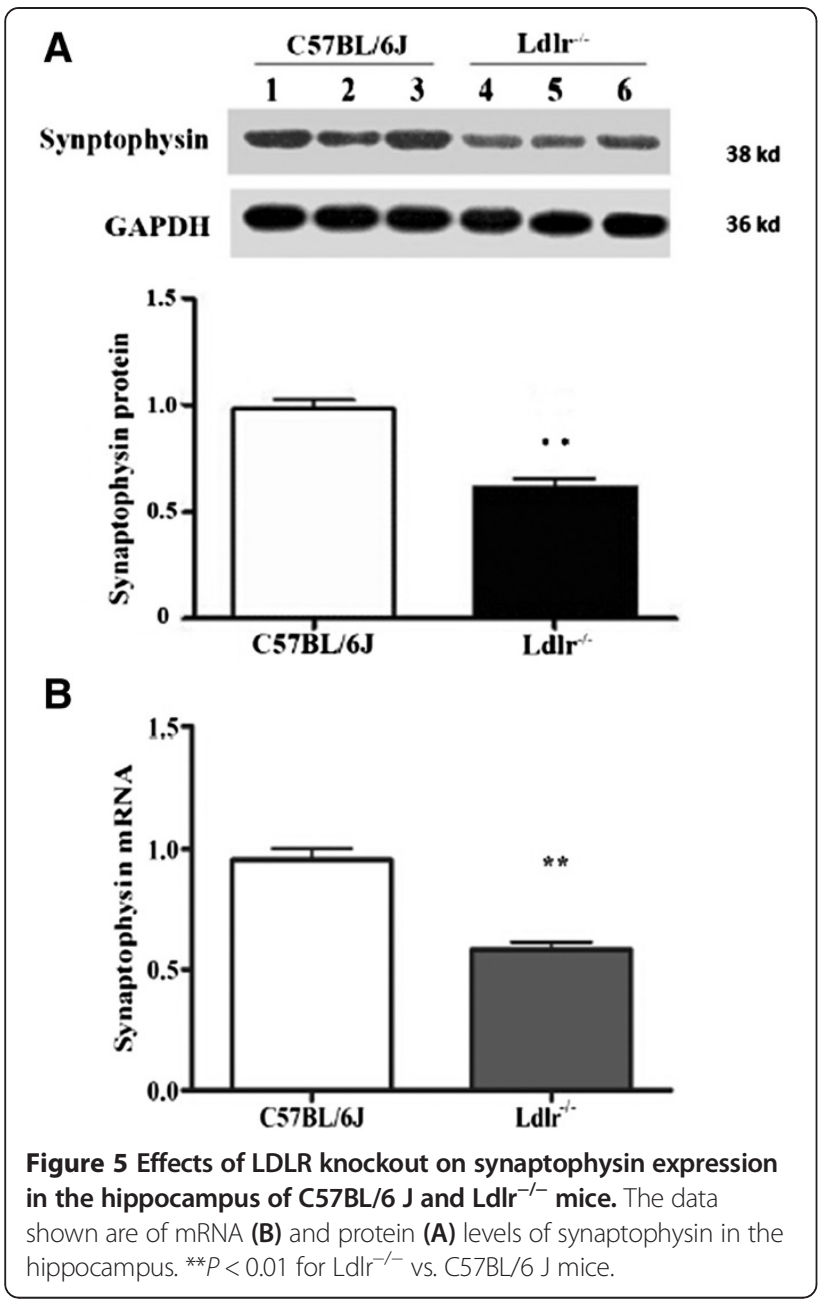

\section{Discussion}

The LDLR is well known for its role in peripheral cholesterol homeostasis [36]; however, it has only been within the last decade has the investigation of cholesterol metabolism in the brain gained momentum [37]. This increased interest is most likely because cerebral cholesterol is implicated in neurodegenerative disease. Here, we used $\mathrm{Ldlr}^{-/-}$mice to imitate the deregulation of cerebral cholesterol. The most striking findings of this study are that $\mathrm{Ldlr}^{-/-}$mice show impaired spatial cognition together with increased intracellular lipid deposition, decreased synapse density and increased neuronal apoptosis in the hippocampus.

Consistent with previous studies $[28,38]$, our data showed that plasma TC and LDL-c levels in 12-monthold $\mathrm{Ldlr}^{-/-}$mice increased two- and seven-fold, respectively, when fed a standard laboratory chow diet. Unlike humans, LDLR deficiency in mice did not increase plasma lipids significantly. However, ultrastructural studies revealed a rich deposition of intracellular lipid in glial cells, providing direct evidence of the disordered cholesterol metabolism in brains of $\mathrm{Ldlr}^{-/-}$mice. ApoE is generated exclusively by glial cells, and these cells are most likely the source of the cholesterol-apoE particles. The deposition of lipid particles results from a decrease in cholesterol-apoE particle uptake by neurons. Thus, we infer that LDLR deficiency in mice affects cholesterol metabolism in brain rather than the peripheral circulation.

Absence of Ldlr might have (or most likely) contributed to impaired spatial cognition, which was observed previously using the MWM test in 6-month-old mice [39]. They display a decreased number of synaptophysinimmunoreactive presynaptic boutons (SIBPs) in the hippocampus CA1. The MWM test has been proven correlate with hippocampal synaptic plasticity [40]. Our behavioural data were supported by the observation that $\mathrm{Ldlr}^{-1-}$ mice displayed a decrease in synapse density/number, as shown by the reduced SIBPs in hippocampal DG other than CA1 regions and the decreased expression of synaptophysin. Ultrastructural examination of $\mathrm{Ldll}^{-/-}$mice revealed multiple synaptic changes, including decreased vesicles and widened clefts in the DG. A decrease in synapses is one of the characteristics of neurodegenerative diseases [41]. Whether it occurs before the death of neurons remains inconclusive; however, it certainly correlates with neuronal degeneration and death. The hippocampal DG region is one of few brain structures currently known to have high rates of neurogenesis in adult rats [42], contributing to the formation of new episodic memories [43], the spontaneous exploration of novel environments, and other functions [44]. Neurons created in the DG must be established synaptically into the circuitry before they are mature [45]. Synapses contain large membranes in postsynaptic spines and in presynaptic vesicles, which have a particularly high content of cholesterol [46]. A continuous supply of cholesterol is required for synaptogenesis, the results may be explained by the possibility that reduced cellular uptake of cholesterol in $\mathrm{Ldlr}^{-/-}$mice underlies the reduction in synaptic plasticity. In contrast, although the mean cerebral total cholesterol content in $\mathrm{Ldlr}^{-1-}$ mice did not differ from that of C57BL/6 J mice [25], research has shown that cholesterol distribution in the plasma membrane is uneven and that the LDLR plays a role in modulating the transbilayer or asymmetric distribution of cholesterol in the exofacial and cytofacial leaflets of the synaptic plasma membranes. $\mathrm{Ldlr}^{-/-}$mice have been shown to display an increase in the percentage distribution of cholesterol and decreased fluidity in the exofacial leaflet [27], which may affect synaptic transmission. Changes intransbilayer or asymmetric distribution of cholesterol may increase $A \beta$ deposition in the brain $[47,48]$ and enhance synaptic excitotoxicity $[49,50]$.

The most important feature of AD pathology is neurodegeneration. It has been well documented that some pathological neuronal loss in AD occurs via apoptosis. 

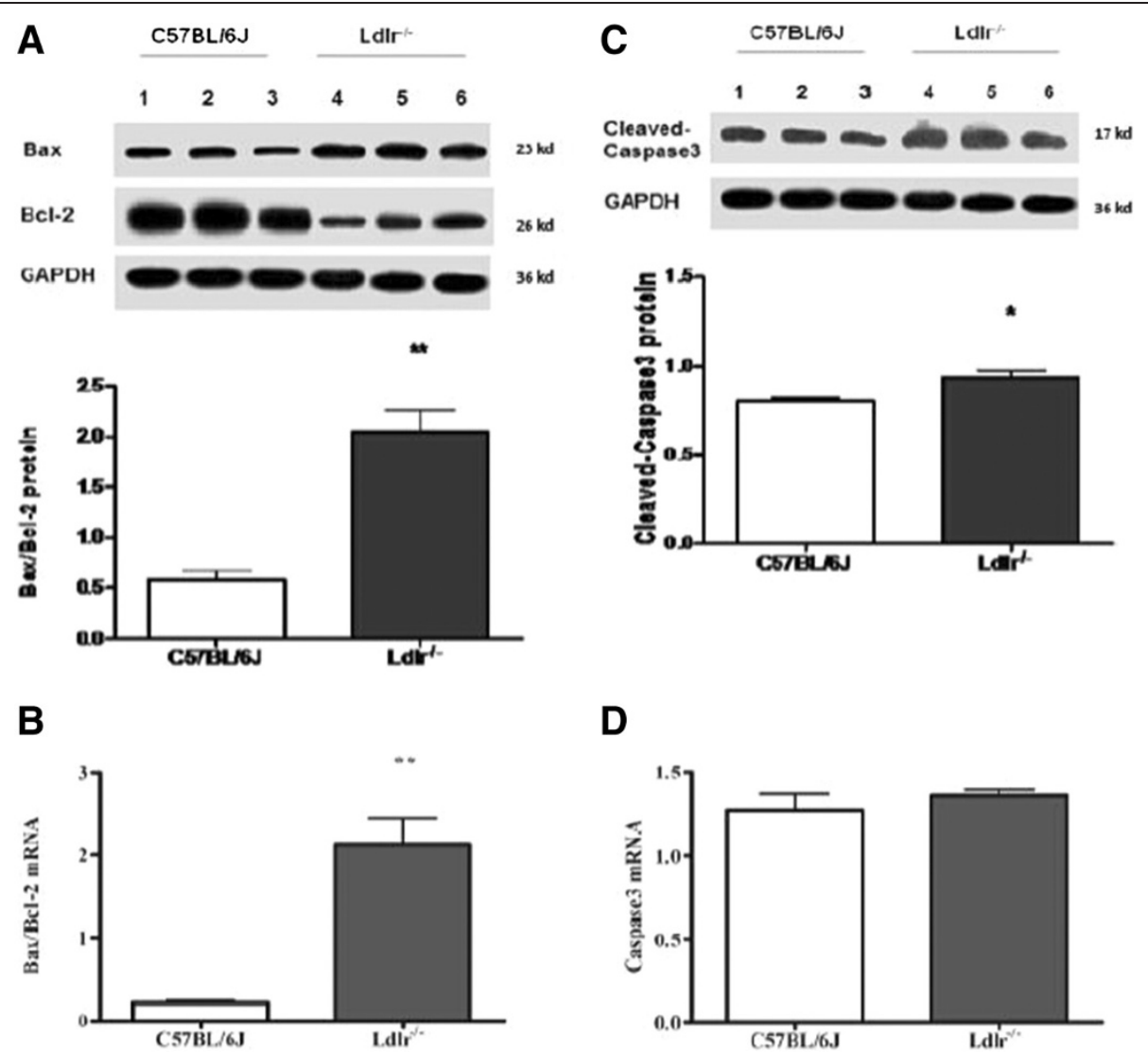

D
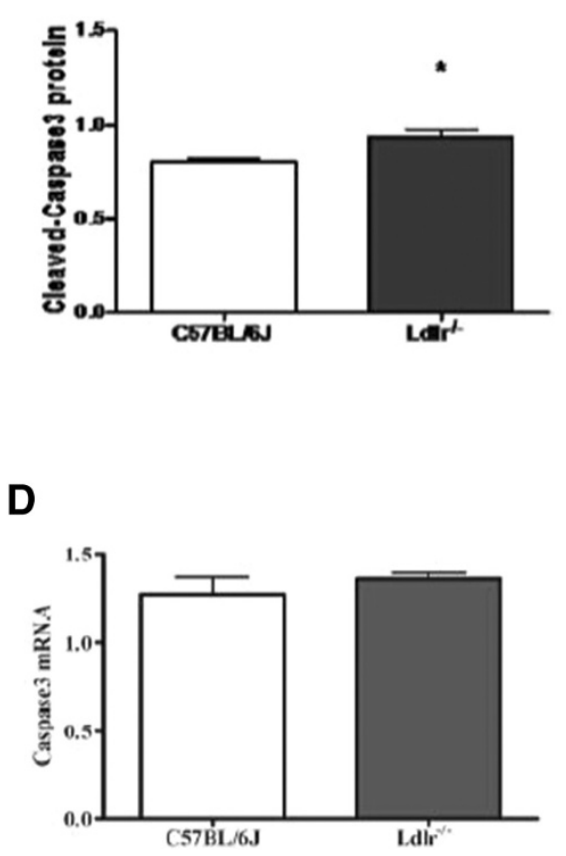

Figure 6 Effects of LDLR knockout on expression of the apoptosis-related genes $\mathrm{Bax}, \mathrm{Bcl}-2$ and caspase3 in the hippocampus of C57BL/6 J and Ldlr ${ }^{-1-}$ mice. The data shown are the ratio of protein (A) and mRNA (B) levels of Bax to Bcl-2, the levels of activated-caspase3 protein $(\mathbf{C})$ and caspase-3 mRNA (D) are also quantified in the hippocampus. ${ }^{*} P<0.05,{ }^{* *} P<0.01$ for $\mathrm{Ldll}^{-1-}$ vs. C57BL/6 J mice.

In the present study, the pro-apoptotic gene bax was expressed at higher levels, and expression of the antiapoptotic gene bcl-2 was lower at both the mRNA and protein levels in the hippocampus of $\mathrm{Ldll}^{-/-}$mice. These results indicate that $\mathrm{Ldlr}^{-1-}$-mediated distribution of brain cholesterol metabolism led to an increase in apoptosis. $\mathrm{Ldlr}^{-1-}$-mediated reduced cellular uptake of cholesterol may promote neuronal death. A deterioration intransbilayer or asymmetric distribution of cholesterol contributes to $A \beta$ deposition, and $A \beta$ oligomers have been shown to induce neuronal apoptosis via the SM-ceramide pathway [51]. In hippocampal DG, $\mathrm{Ldlr}^{-/-}$-induced apoptotic injury potentially suppress the formation of new neurons, and their integration into the neuronal circuitry of the hippocampal network was further hindered through weakening synaptic connections.

Certain limitations existed when we interpreted the data presented in this study. Cholesterol metabolism in mice differs substantially from that in humans. Although it is unknown whether differences in lipoprotein metabolism in the brain exist between mice and humans, a recent cohort study revealed that $\mathrm{Ldlr}^{-/-}$patients showed a six-fold higher incidence of mild cognitive impairment compared with those without Ldlr mutations [22], indicating that LDLR may play similar roles in brain cholesterol metabolism and in maintaining brain function in both humans and mice. Although some ultra-structural changes were observed using transmission electron microscopy, these changes could not be the direct evidence that indicating deterioration in cholesterol homeostasis in the brain. We cannot explain the exact mechanisms that link apoptosis and synapses deficit to the possible brain cholesterol dyshomeostasis. We also should have studied the levels of various neurotransmitters in various areas of the brain, to show that the impaired spatial cognition is only due to synaptophysin but not due to changes in neurotransmitters. But the neurotransmitters in the brain are very complex, the changes of synaptophysin itself may be caused by other neurotransmitters, and vice versa [52-54]. So that it is very difficult to eliminate the effects of these confounding factors. Additionally, the number of animals used for the cellular and molecular biology assays is low. Apoptotic markers like Annexin V or others may be used to quantify the amount of apoptosis. 
This study has demonstrated the adverse effects of cholesterol deregulation in the brain on spatial cognition in the $\mathrm{Ldll}^{-/-}$mouse model. Our findings indicate that LDLR deficiency results in impaired spatial cognition most likely via its deteriorating effect on homeostasis of cerebral cholesterol and negative effects on hippocampal vulnerability to apoptosis and number of synapses. These results will be helpful in understanding the role of LDLR in cholesterol-related cognitive impairment.

\section{Competing interests}

The authors declare that they have no competing interests.

\section{Authors' contribution}

The authors contributions were as follows: SW and YY designed the study. YH and WX obtained all images. YH performed statistical analysis and wrote the first manuscript draft. SW, PW and RH helped to revise the final version of paper. All authors have read and approved the final manuscript. SW and $\mathrm{YH}$ contributed equally to this article and are equal co-first authors.

\section{Acknowledgements}

This work was partially supported by the National Natural Science Foundation of China (No. 81370921, Wang SH; No. 30870870, Wang SH; No. 81070638, Wang SH; and No. 81070916, Guo YJ), the Natural Science Foundation of JiangSu Province (No. BK2011601, Yuan Y), and the Social Development Project of JiangSu Province (No. SBE201170735, Wang SH).

\section{Author details}

'Department of Endocrinology, ZhongDa Hospital of Southeast University, No.87 DingliaQiao Road, Nanjing 210009, PR China. ${ }^{2}$ Department of Endocrinology, YanCheng First People's Hospital, No.16 YueHe Road, YanCheng 224005, PR China.

Received: 18 August 2014 Accepted: 11 November 2014 Published: 20 November 2014

\section{References}

1. Puglielli L, Tanzi RE, Kovacs DM: Alzheimer's disease: the cholesterol connection. Nat Neurosci 2003, 6:345-351

2. Vance JE, Hayashi H, Karten B: Cholesterol Homeostasis in Neurons and Glial Cells. In Seminars in Cell \& Developmental Biology; 2005:193.

3. Wollmer MA: Cholesterol-related genes in Alzheimer's disease. Biochim Biophys Acta 2010, 1801:762-773.

4. Tint G, Salen G, Batta AK, Shefer S, Irons M, Elias ER, Abuelo DN, Johnson VP, Lambert M, Lutz R: Correlation of severity and outcome with plasma sterol levels in variants of the Smith-Lemli-Opitz syndrome. J Pediat 1995, 127:82-87.

5. Chang T-Y, Reid PC, Sugii S, Ohgami N, Cruz JC, Chang CC: Niemann-Pick type C disease and intracellular cholesterol trafficking. I Biol Chem 2005, 280:20917-20920.

6. Jick H, Zornberg GL, Jick SS, Seshadri S, Drachman DA: Statins and the risk of dementia. Lancet 2000, 356:1627-1631.

7. Jarvik G, Wijsman EM, Kukull W, Schellenberg G, Yu C, Larson E: Interactions of apolipoprotein E genotype, total cholesterol level, age, and sex in prediction of Alzheimer's disease a case-control study. Neurology 1995, 45:1092-1096

8. Kivipelto $M$, Helkala E-L, Laakso MP, Hänninen T, Hallikainen M, Alhainen $K_{\text {, }}$ livonen S, Mannermaa A, Tuomilehto J, Nissinen A: Apolipoprotein E epsilon4 allele, elevated midlife total cholesterol level, and high midlife systolic blood pressure are independent risk factors for late-life Alzheimer disease. Ann Intern Med 2002, 137:149.

9. Barres BA, Smith SJ: Cholesterol-making or breaking the synapse. Science 2001, 294:1296-1297.

10. Wahrle SE, Jiang H, Parsadanian M, Hartman RE, Bales KR, Paul SM, Holtzman DM: Deletion of Abca1 increases A $\beta$ deposition in the PDAPP transgenic mouse model of Alzheimer disease. J Biol Chem 2005, 280:43236-43242.

11. Poirier J: Apolipoprotein $\mathrm{E}$ and cholesterol metabolism in the pathogenesis and treatment of Alzheimer's disease. Trends Mol Med 2003, 9:94-101.
12. Papassotiropoulos A, Streffer JR, Tsolaki M, Schmid S, Thal D, Nicosia F, lakovidou V, Maddalena A, Lutjohann D, Ghebremedhin E: Increased brain \{beta\}-amyloid load, phosphorylated tau, and risk of Alzheimer Disease associated with an intronic CYP46 polymorphism. Arch Neurol 2003, 60:29.

13. Michikawa M: The role of cholesterol in pathogenesis of Alzheimer's disease. Mol Neurobiol 2003, 27:1-12.

14. de Chaves EIP, Rusiñol AE, Vance DE, Campenot RB, Vance JE: Role of lipoproteins in the delivery of lipids to axons during axonal regeneration. J Biol Chem 1997, 272:30766-30773.

15. Jeon H, Blacklow SC: Structure and physiologic function of the lowdensity lipoprotein receptor. Annu Rev Biochem 2005, 74:535-562.

16. Hussain MM, Strickland DK, Bakillah A: The mammalian low-density lipoprotein receptor family. Annu Rev Nutr 1999, 19:141-172.

17. Dehouck B, Fenart L, Dehouck MP, Pierce A, Torpier G, Cecchelli R: A new function for the LDL receptor: transcytosis of LDL across the blood-brain barrier. J Cell Biol 1997, 138:877-889.

18. Hofmann SL, Russell DW, Goldstein JL, Brown MS: mRNA for low density lipoprotein receptor in brain and spinal cord of immature and mature rabbits. Proc Natl Acad Sci 1987, 84:6312-6316.

19. Swanson LW, Simmons DM, Hofmann SL, Goldstein JL, Brown MS: Localization of mRNA for low density lipoprotein receptor and a cholesterol synthetic enzyme in rabbit nervous system by in situ hybridization. Proc Natl Acad Sci 1988, 85:9821-9825.

20. Dietschy JM, Turley SD: Thematic review series: brain Lipids. Cholesterol metabolism in the central nervous system during early development and in the mature animal. J Lipid Res 2004, 45:1375-1397.

21. Björkhem I, Meaney S: Brain cholesterol: long secret life behind a barrier. Arterioscler Thromb Vasc Biol 2004, 24:806-815.

22. Zambón D, Quintana M, Mata P, Alonso R, Benavent J, Cruz-Sánchez F, Gich J, Pocoví M, Civeira F, Capurro S: Higher incidence of mild cognitive impairment in familial hypercholesterolemia. Am J Med 2010, 123:267-274.

23. Lendon CL, Talbot CJ, Craddock NJ, Han SW, Wragg M, Morris JC, Goate AM: Genetic association studies between dementia of the Alzheimer's type and three receptors for apolipoprotein $\mathrm{E}$ in a Caucasian population. Neurosci Lett 1997, 222:187-190.

24. Katsouri L, Georgopoulos S: Lack of LDL receptor enhances amyloid deposition and decreases glial response in an Alzheimer's disease mouse model. PLoS One 2011, 6:e21880.

25. Cao D, Fukuchi K, Wan H, Kim H, Li L: Lack of LDL receptor aggravates learning deficits and amyloid deposits in Alzheimer transgenic mice. Neurobiol Aging 2006, 27:1632-1643.

26. Kim J, Castellano JM, Jiang H, Basak JM, Parsadanian M, Pham V, Mason SM, Paul SM, Holtzman DM: Overexpression of low-density lipoprotein receptor in the brain markedly inhibits amyloid deposition and increases extracellular A 3 clearance. Neuron 2009, 64:632-644.

27. Igbavboa U, Avdulov NA, Chochina SV, Wood WG: Transbilayer distribution of cholesterol is modified in brain synaptic plasma membranes of knockout mice deficient in the low-density lipoprotein receptor, apolipoprotein E, or both proteins. J Neurochem 1997, 69:1661-1667.

28. Ishibashi S, Brown MS, Goldstein JL, Gerard RD, Hammer RE, Herz J: Hypercholesterolemia in low density lipoprotein receptor knockout mice and its reversal by adenovirus-mediated gene delivery. J Clin Investig 1993, 92:883.

29. UCHIDA K, URABE K, NARUSE K, OGAWA Z, MABUCHI K, ITOMAN M: Hyperlipidemia and hyperinsulinemia in the spontaneous osteoarthritis mouse model, STR/Ort. Exp Anim 2009, 58:181-187.

30. Biessels GJ, Kamal A, Urban IJA, Spruijt BM, Erkelens DW, Gispen WH: Water maze learning and hippocampal synaptic plasticity in streptozotocindiabetic rats: effects of insulin treatment. Brain Res 1998, 800:125-135.

31. Vorhees CV, Williams MT: Morris water maze: procedures for assessing spatial and related forms of learning and memory. Nat Protoc 2006, 1:848-858.

32. Hellwig S, Hack I, Kowalski J, Brunne B, Jarowyj J, Unger A, Bock HH, Junghans $D$, Frotscher M: Role for Reelin in neurotransmitter release. J Neurosci 2011, 31:2352-2360.

33. Ojo B, Rezaie P, Gabbott PL, Davies H, Colyer F, Cowley TR, Lynch M, Stewart MG: Age-related changes in the hippocampus (loss of synaptophysin and glial-synaptic interaction) are modified by systemic treatment with an NCAM-derived peptide, FGL. Brain Behav Immun 2011, 26:778-788

34. Cai Q, Gerwin C, Sheng Z-H: Syntabulin-mediated anterograde transport of mitochondria along neuronal processes. J Cell Biol 2005, 170:959-969. 
35. Lull ME, Levesque S, Surace MJ, Block ML: Chronic apocynin treatment attenuates beta amyloid plaque size and microglial number in hAPP (751) SL mice. PLoS One 2011, 6:e20153.

36. Mulder M, Koopmans G, Wassink G, Al Mansouri G, Simard ML, Havekes LM, Prickaerts J, Blokland A: LDL receptor deficiency results in decreased cell proliferation and presynaptic bouton density in the murine hippocampus. Neurosci Res 2007, 59:251-256.

37. Pfrieger FW, Ungerer $\mathrm{N}$ : Cholesterol metabolism in neurons and astrocytes. Prog Lipid Res 2011, 50:357-371.

38. Elder GA, Ragnauth A, Dorr N, Franciosi S, Schmeidler J, Haroutunian V Buxbaum JD: Increased locomotor activity in mice lacking the low-density lipoprotein receptor. Behav Brain Res 2008, 191:256-265.

39. Mulder M, Jansen PJ, Janssen BJ, van de Berg WD, van der Boom H, Havekes LM, de Kloet RE, Ramaekers F, Blokland A: Low-density lipoprotein receptor-knockout mice display impaired spatial memory associated with a decreased synaptic density in the hippocampus. Neurobiol Dis 2004, 16:212-219.

40. Choi J-H, Park P, Baek G-C, Sim S-E, Kang SJ, Lee Y, Ahn S-H, Lim C-S, Lee Y-S, Collingridge GL: Effects of PI3Ky overexpression in the hippocampus on synaptic plasticity and spatial learning. Molecular Brain 2014, 7:78.

41. Sheng M, Sabatini BL, Südhof TC: Synapses and Alzheimer's disease. Cold Spring Harb Perspect Biol 2012, 4:a005777.

42. Cameron HA, Mckay RD: Adult neurogenesis produces a large pool of new granule cells in the dentate gyrus. J Comp Neurol 2001, 435:406-417.

43. Amaral DG, Scharfman HE, Lavenex P: The dentate gyrus: fundamental neuroanatomical organization (dentate gyrus for dummies). Prog Brain Res 2007, 163:3-790.

44. Scharfman HE: The Dentate Gyrus: A Comprehensive Guide to Structure, Function, and Clinical Implications. Elsevier; 2007.

45. Carlén M, Cassidy RM, Brismar H, Smith GA, Enquist LW, Frisén J: Functional integration of adult-born neurons. Curr Biol 2002, 12:606-608.

46. Takamori S, Holt M, Stenius K, Lemke EA, Grønborg M, Riedel D, Urlaub H, Schenck S, Brügger B, Ringler P: Molecular anatomy of a trafficking organelle. Cell 2006, 127:831-846.

47. Abad-Rodriguez J, Ledesma MD, Craessaerts K, Perga S, Medina M, Delacourte A, Dingwall C, De Strooper B, Dotti CG: Neuronal membrane cholesterol loss enhances amyloid peptide generation. J Cell Biol 2004, 167:953-960.

48. Burns MP, Igbavboa U, Wang L, Wood WG: Cholesterol distribution, not total levels, correlate with altered amyloid precursor protein processing in statin-treated mice. Neruomol Med 2006, 8:319-328.

49. Li S, Shankar GM, Selkoe DJ: How do soluble oligomers of amyloid $\beta$-protein impair hippocampal synaptic plasticity? Front Cell Neurosci 2010, 4:5.

50. Bordji K, Becerril-Ortega J, Buisson A: Synapses, NMDA receptor activity and neuronal $A \beta$ production in Alzheimer's disease. Rev Neurosci 2011 22:285-294

51. Malaplate-Armand C, Florent-Béchard S, Youssef I, Koziel V, Sponne I, Kriem B, Leininger-Muller B, Olivier J-L, Oster T, Pillot T: Soluble oligomers of amyloid- $\beta$ peptide induce neuronal apoptosis by activating a $\mathrm{CPLA}<\mathrm{sub}>$ $2</$ sub $>-$ dependent sphingomyelinase-ceramide pathway. Neurobiol Dis 2006, 23:178-189.

52. Mitew S, Kirkcaldie MT, Dickson TC, Vickers JC: Altered synapses and gliotransmission in Alzheimer's disease and AD model mice. Neurobiol Aging 2013, 34:2341-2351.

53. Russell CL, Semerdjieva S, Empson RM, Austen BM, Beesley PW, Alifragis P: Amyloid- $\beta$ acts as a regulator of neurotransmitter release disrupting the interaction between synaptophysin and VAMP2. PLoS One 2012, 7:e43201.

54. Alder J, Kanki H, Valtorta F, Greengard P, Poo M: Overexpression of synaptophysin enhances neurotransmitter secretion at Xenopus neuromuscular synapses. J Neurosci 1995, 15:511-519.

doi:10.1186/1476-511X-13-175

Cite this article as: Wang et al: LDL receptor knock-out mice show impaired spatial cognition with hippocampal vulnerability to apoptosis and deficits in synapses. Lipids in Health and Disease 2014 13:175.

\section{Submit your next manuscript to BioMed Central and take full advantage of:}

- Convenient online submission

- Thorough peer review

- No space constraints or color figure charges

- Immediate publication on acceptance

- Inclusion in PubMed, CAS, Scopus and Google Scholar

- Research which is freely available for redistribution

Submit your manuscript at www.biomedcentral.com/submit 